\title{
Passwords
}

Volume 13 | Issue 1

Article 18

$12-20-2012$

\section{Dying in Wyoming}

Alex Genty-Waksberg

aggw2011@mymail.pomona.edu

Follow this and additional works at: http://scholarship.claremont.edu/passwords

Part of the Art and Design Commons, Creative Writing Commons, and the Photography Commons

\section{Recommended Citation}

Genty-Waksberg, Alex (2012) "Dying in Wyoming," Passwords: Vol. 13: Iss. 1, Article 18. DOI: 10.5642/passwrd.20121301.18 Available at: http://scholarship.claremont.edu/passwords/vol13/iss1/18

This Story is brought to you for free and open access by the Journals at Claremont at Scholarship @ Claremont. It has been accepted for inclusion in

Passwords by an authorized administrator of Scholarship@ Claremont. For more information, please contact scholarship@cuc.claremont.edu. 


\section{Dying in Wyoming \\ Alex Genty-Waksberg}

Thirty years ago he liked a band and so did she. Twenty nine years ago, he realized he liked her and so did she. Eighteen years ago, they held each other and tried to think of anything else, so as not to jinx it. She whispered her social security number as he came shamelessly inside of her. Seven months later, they decided on just Pam because a hyphenated last name was enough stress for a child. Pam would decide seven years later that she was named after a popular doll, Princess Pam, which she predated by four years. Her parents did not object, though, and the origin was upheld. Eight years ago, Pam met a boy who didn't find her disgusting and even looked her in the eye. The first boy, she would remember. Pam was unimpressed and decided to hold out for better options. Two years later, Pam would get braces and promptly stop smiling forever.

Four years ago, Pam learned about the history of America. Or maybe it was of somewhere else, she could never remember. More importantly, four years ago, Pam watched a classroom full of mindless motions. She watched everyday as Charlie left his seat at 10:18 and returned precisely six minutes later. Pam looked on at the locking and unlocking fingers of Ren and Sam, giving their sweaty hands a short breather every three minutes. Pam even watched Mr. Bradley occasionally, though not often. She noticed that after saying the name of a war, he would twist his mustache. Twice left and then once right. Sometimes Pam wondered if this uneven twisting would leave his mustache to be always left-leaning. But then Brandon would pucker his lips and whistle "Pomp and Circumstance" right on cue and Pam would forget her thought. No one minded that Brandon whistled this every twelve minutes, they just wondered to each other why he chose that specific song. Brandon had never and would never attend a graduation for the duration of his life. He died happily, believing the tune to be some kind of Israeli folksong he picked up as a child. Pam couldn't understand the automatic, monotonous way in which every one went about their business. She put thought and meaning into every move she made. She would try to go on autopilot, but within seconds a flickering lightbulb or whining chair would demand her careful consideration.

Two years ago, Pam focused her attention on the thin red needle above her head, which was moving, to Pam's delight, at a circular and precise pace. 
In the sweaty, chaotic gymnasium, she welcomed the dependability of the clock's constant progress. She tried to turn her attention to the thicker black needle, but the second hand would not cease and eventually won out. She knew that the time was 1:24 and 32 seconds, but she could not remember if it was March 9th or September 3rd. Pam wished the clock had a fourth and fifth needle (preferably blue and green) which gave the date as well. What good is the time if you don't know what day it is?

At 1:27 and 48 seconds, Ray slipped a plain white note into Pam's locker. Ray inserted his whole head in the locker (just to see that he could) and carefully placed the note in Pam's left Converse shoe. This was her favorite shoe, if she was forced to choose between the right and left. Her left shoe was an inch too big and she enjoyed slipping in and out of it while the teacher wasn't looking. Ray noticed things too and knew this about Pam. At 1:28 and 3 seconds, Ray left the locker room. Pam saw him exit, but suspected that this was just another daily routine she hadn't yet picked up on. Besides, Pam didn't need to devote much time to thinking about Ray. He was quiet and small and looked like he would bald from sheer weakness. Sometimes Pam caught Ray staring at her. She would stare right back, harder, and he would quickly evaporate to her delight.

Three hours and a mile or so later, Pam entered her house and removed her shoes. Attached to her sock, Pam found a note smudged with pencil and foot sweat. The note read, "I like you. I think." Pam immediately recognized the indecisiveness as belonging to Ray. She cared less about the proclamation and more about the sloppy lettering of the short note. Every force in her body wanted to straighten out his k's and fatten up his n's. This, she gathered, was the point of a relationship. Pam had noticed other things about Ray.

1 He wore glasses up until three months ago. Now he just squinted.

2 He never wore socks that went past his ankles except maybe when he had long pants on. There was no way of knowing what socks he wore with his long pants.

3 Sometimes he would walk into seventh period sweating profusely. On these days he would kindly keep his distance from his classmates.

4 When no one was looking, Ray would pick his nose with his left index finger. Bloody noses often ensued, which he learned to deal with.

5 Sometimes Ray cried. Not too much, in his opinion, but more, it seemed, than other boys. Pam did not actually know this about Ray but she figured as much. 
Eight minutes and an indeterminate amount of seconds later (the clock on the oven was not as precise as Pam would have preferred) Ray received a phone call from a girl asking for Ray. Of course Ray knew the voice belonged to Pam, he had studied her voice enough, but he was unsure if he was ready to field the call. Ray had no decision to make, though. Pam recognized Ray's voice before he picked up the phone. Still, both parties played along for a couple of beats before Ray took responsibility.

"I got your note, Ray."

"What did it say again?"

"I like you. I think."

"You think that's what it said?"

"No, you wrote the I think in your note."

"I didn't mean that. I do like you.

"I know you do."

"I'm embarrassed."

"I can tell."

"I should've used a colored pencil."

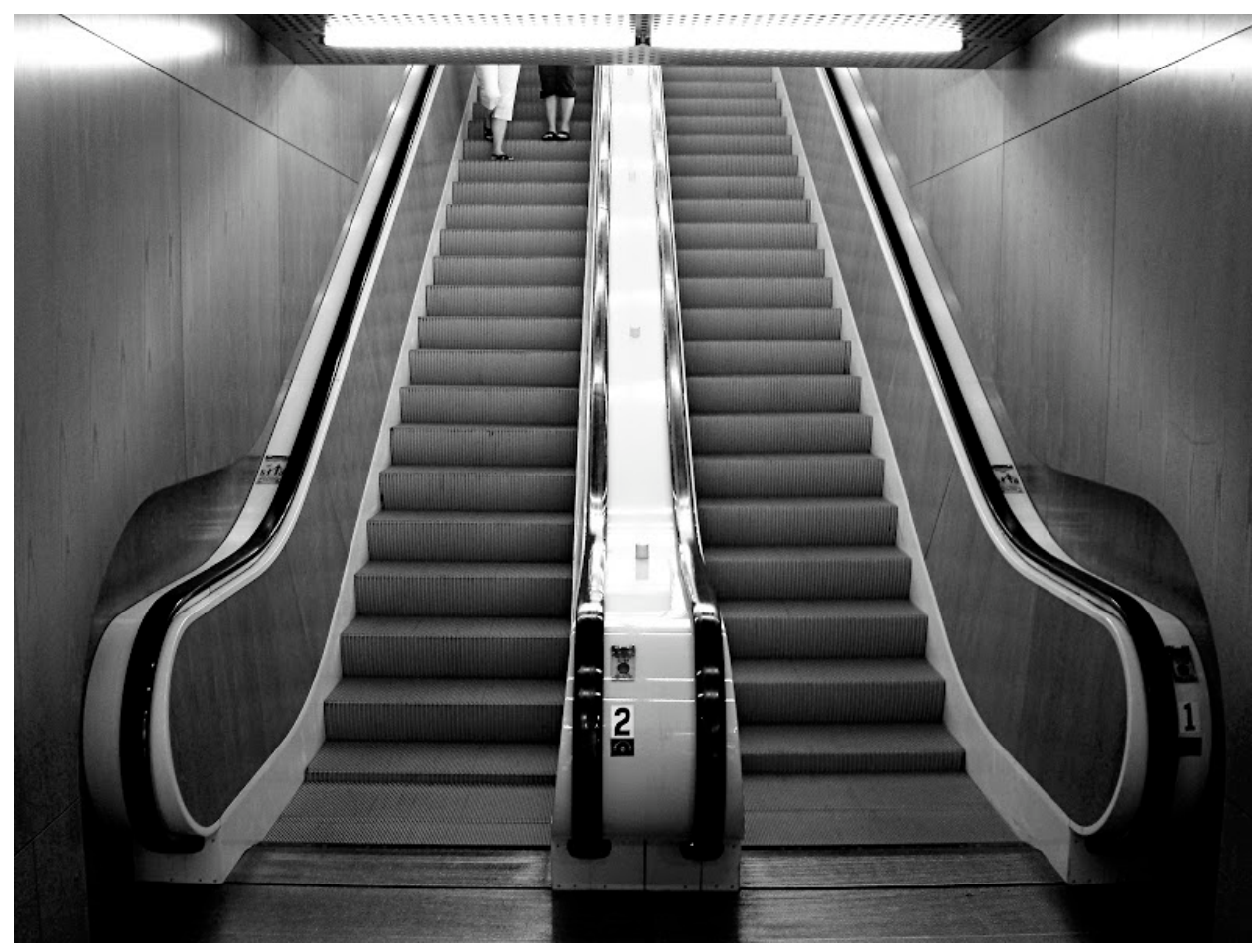


"Blue. Aqua maybe."

"Did it smudge at all?"

"Yes. But only because I walked on it."

"You walked on my note?"

"I didn't walk on you. It was just paper."

"Do you like me? Do you think you like me?

"I haven't decided yet. I think probably not."

"I have to go."

Pam listened to Ray take four and a half deep breaths before hanging up the phone.

One year and seven months ago, Pam's heart beat fast, like really fast. She couldn't concentrate long enough to count each beat, but it appeared to be throbbing at a fairly regular pace. Pam, for once, didn't care if the beating was symmetrical or not. She refused another hit, but Pam was nonetheless very high. Pam enjoyed the heaviness that surrounded her body after the second or third hit (or first with a bong). For a couple of hours, Pam could take her mind off that faucet that no one bothers to turn off correctly or Keith's stupid haircut that he flips every second and a half, and just relax. She slid back and the sofa put its arms around her, engulfing her small body completely. Shed of her obsessive goggles, Pam had begun to get to know people better. Her friends, the most symmetrical and repetitive group of people she could find, were very boring. Pam, of all people understood the importance of convention and routine, but there had to be more to life! She could watch Kyle adjust his collar, which he did every two minutes and fifteen seconds, for hours. But when the boy opened his mouth, an occasional quote from Cheers was the best anyone could hope for, and some Airhead-tinted spit if you were lucky.

Jane wasn't much more entertaining. She seemed exhausted by life and delivered her words as though it was the fifth or sixth time she was repeating them. Pam tried to focus on the back of Jane's dress, which flew up every four minutes from her unabashed farting, but it didn't hold the intrigue it once had. Pam started to feel small and alone. Whenever she had felt this way before, she would lock in on some pattern, any kind, and become immersed in it. Pam searched desperately for an escape, but on this day, her trick didn't work. She felt her stomach slink farther down into her shivering body. She felt like sweating but the weed had dried out her body. No matter how hard she tried, she couldn't blink at a consistent beat. Meanwhile, Kyle and Jane 
sucked each other's faces loudly. This came as a minor relief to Pam; the two made out every fourth time that they hung out. Pam suddenly realized how many nights had ended with Pam watching Kyle and Jane exchange the fuel for their useless mouths until her mom came to pick her up.

Pam was depressed. She felt the lightness of her life, nothing of worth to hold it down. She recognized her current state but understood her depression to be out of reach of any mild drug. It was as though the immense boredom that she had somehow ducked her whole life had all at once slimed her. Pam stood up suddenly and made a move towards the door. It was 10:13 and 17 seconds. She could still catch the last forty-five minutes of that documentary about Tarzan on TCM. Or she could eat seven and a half donuts. That was also an option.

"Where are you going?" Jane had suctioned her face off of Kyle. She didn't seem particularly interested in the question or the ensuing answer.

"I think I hate you guys. I think I'm unhappy."

"You said the same thing last week. You'll get over it." Pam neither knew nor cared about distinguishing Jane and Kyle from each other at this point.

'No I didn't. I've never said anything like this before. You guys blatantly don't listen to me. I never thought enough before to know that I was unhappy."

"Could I get a couple bucks for the weed?"

"Fuck you, Kane. Or Jyle. I'm going to go home and eat nine donuts. And then after, when I feel too full I'm going to think of you guys. So then I start associating that feeling with both of you."

"You could only eat seven donuts, tops."

“That's why I chose nine. I'm going to feel terrible." Kyle started to move his thumb toward his lips.

"Stop it!"

"What?"

"Every four minutes and seventeen seconds, you flatten out the peach fuzz on your upper lip." Kyle stared at his thumb as though he'd never seen it before. Like it had just sprouted.

"I wouldn't say peach fuzz."

Thirteen minutes and four donuts later, Pam let out a heavy sigh filled with shame and chocolate. The sigh may have been overdone, but she felt that she deserved it. She heard a soft whining outside, but did not immediately make a move. The last thing she wanted was to be disturbed from her 


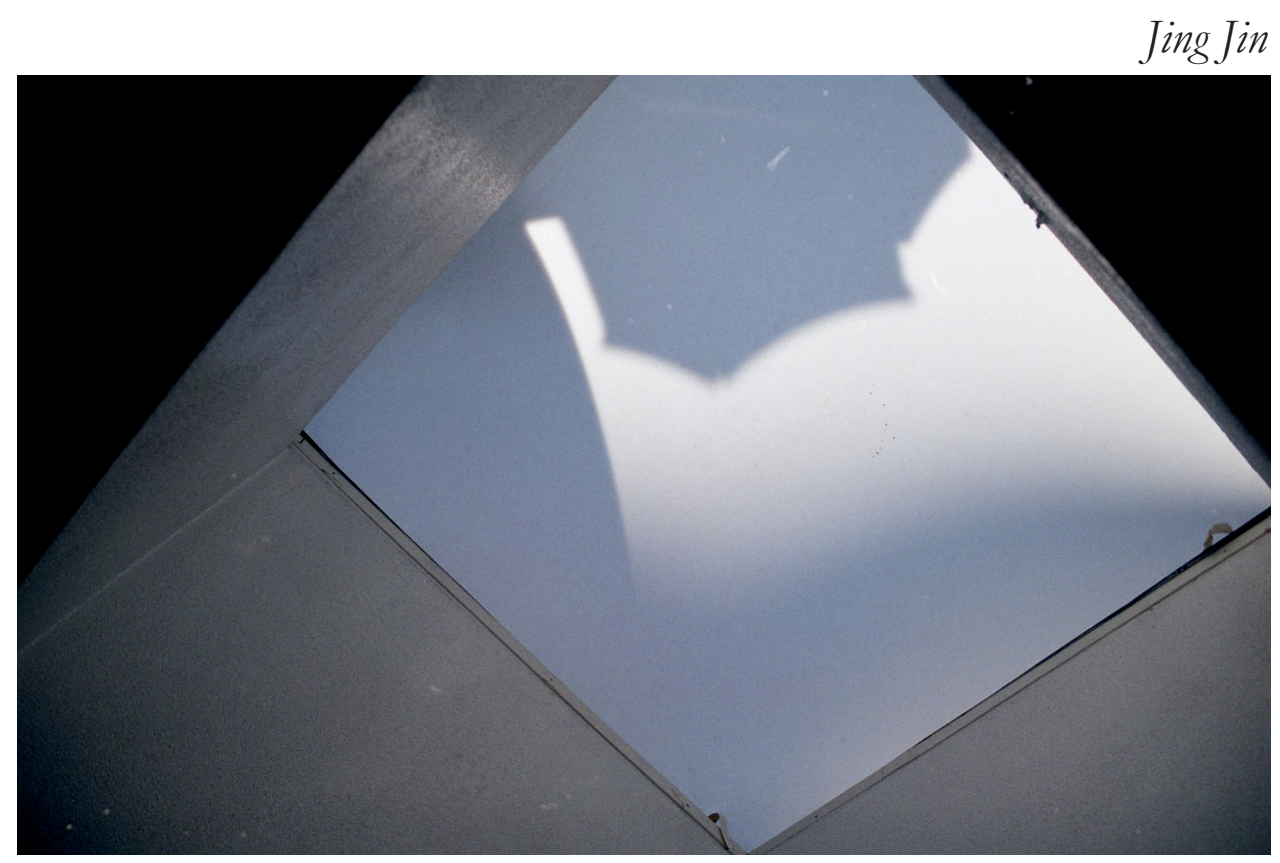

self-pity. Two minutes later, she heard the same noise. She groaned, hoping someone would hear her reluctance, and ventured outside. It was an especially dark night and she could only hear the whining, a little louder now. It was only after Pam displayed her flashlight app that she saw the giraffe standing next to the tree in her front yard. Pam was no longer high, but now wished she was. She started to turn back to her front door, ready to completely ignore the situation, when she again heard the giraffe's moping. The giraffe, Pam noticed, humped the tree furiously every four seconds and then, after two minutes of wooing, would step back and gripe at the lack of response.

It seemed natural to Pam that the giraffe would take a liking to the tree. They seemed like each other's type. Unfortunately, the tree (even if it felt the same way about the giraffe) was unable to reciprocate any feelings. Pam felt uncomfortable watching such a harsh rejection. She was also made uneasy by what seemed to be the rape of a tree. Wanting to end the situation for both parties, Pam slowly approached the giraffe. She liked most animals. True, she had never encountered a giraffe before, but she figured the giraffe couldn't be much different from a dog, or an awkwardly tall human. She knew how to deal with both of those. She softly placed her hand on the giraffe's leg and rubbed it up and down. The giraffe's whining quieted almost immediately. What was now clear to be a he looked down at the small creature that was consoling him. He felt touched by the offer of love at a moment when 
he felt so vulnerable and unattractive. Pam enjoyed looking into the giraffe's eyes. There seemed to be more meaning in his eyes than any words she had ever heard. She also liked his spots.

Pam carefully scaled the tree until she was at a height where she could mount the giraffe. He bowed his head as she climbed onto him. The giraffe didn't walk particularly fast, but the ride was exhilarating nonetheless. He took Pam to all of the high spots he liked around the city. Pam felt a removal from the ground not far beneath her. Pam watched the giraffe closely, but could find none of the habits so common of her own species. The giraffe's unique genetic makeup had nothing to do with it. Pam recalled the animals she had watched in the past go through their daily routines with a robotic sensitivity. It was simply that the giraffe was too present to go through any preconceived motions. And so was Pam. They silently spoke about their dreams and how it could all go wrong. Both creatures felt needy and desperate, but made peace with the fact. Clutching him around his neck, she could feel his cool sweat as he trotted into the emptiness of midnight in the suburbs.

After an hour and thirteen minutes of intense bonding, the giraffe dropped Pam off at her second floor window. Pam did not want to leave, but had no reason to keep the giraffe longer. She kissed the giraffe passionately on his nose. He did not want to see his companion go either. He hung his head in her bedroom for a few more beats. The position was uncomfortable for him, but he didn't mind. Pam wished she could tell his eyes everything. Instead she held his stare for seven more seconds. The giraffe reluctantly backed away from the house and made his way down the street, purposefully giving the tree the cold shoulder.

Pam looked out the window as the giraffe left, concentrating on a spot just above his right butt cheek until it joined with the darkness. Pam hoped the giraffe would return one day, on another shitty night when she needed the absurdity and thrill of riding a giraffe. She had a fleeting thought that maybe the giraffe would come every month or week like clockwork. And she could actually look forward to his cyclic visits. This, though, was a giraffe, not Kyle's upper lip. The creature did not have a schedule and would not keep one, even for Pam. All she could do was hope and pray and situate herself around sexy trees.

Ten minutes ago, Pam had overheard her say she liked this song. Pam had chosen the song herself. The Star Diner was her favorite diner because it was 
never closed, even on Christmas, and it had a jukebox. Her pockets hummed every time she walked in, lined to the brim with quarters. She had been sitting with her friend, Tim, for two hours when the voice came from behind. She had been watching as every three minutes and twenty seconds Tim forked the last piece of color on his plate and put it back down. She was interested to see who had complimented her music with such mild enthusiasm. True, the song was the eleventh song in her three-dollar playlist, but Pam was searching for any kind of distraction from Tim's hollow mouth. Pam turned her head with astoundingly little delicacy. Tim used this opportunity to stuff the last bite of egg down his throat. He had always had a problem taking the last bite of his meal with someone watching.

Pam gasped unintentionally. The girl had met her stare as soon as Pam turned around.

"Hello." Her voice had a shred of expectancy to it. The first thing that Pam noticed was her clothes. They were sloppily placed over her body parts, but not in a way that suggested she had thought any of it out. One arm hung out of the opening, which the shirt had designated for her neck. Some of her clothes screamed rudely while others were shy and soft-spoken. The girl, Pam saw, did not notice in the slightest the civil war going on all around her. Pam, as embarrassed as she might be, could not ignore the girl.

"Hi."

"You put that song on, didn't you?"

"Yeah. And the ten before it."

"Well, I liked the eleventh."

"How'd you know it was me?"

"I saw your neck flinch when I said I liked the song."

"You noticed that?"

"You'd be surprised how interesting a neck can be when you're talking to these people."

Somehow Pam had not noticed the couple sitting across from the girl, closest to Pam. The girl was giving the boy a hand job over the button zipper of his khaki shorts. The boy stared forward, trying to concentrate on the block girl featured on the diner's bathroom door.

"I'm Pam."

"Izzy."

"I'm glad you said something."

"We could've kept missing each other." 
"I'm finished now. We can leave." Tim felt the insignificance of his words even as he said them. Pam used her right hand to shoo Tim away; he was free to leave as he pleased. Pam smiled at Izzy and Izzy saw it and responded. Pam didn't want to, but felt she needed to break the silence.

"What do you want to do?"

"I guess that's the big question now, isn't it?"

Izzy ran her right four fingers through her sloppy hair. Pam couldn't help herself.

"How often do you do that?"

"What, with my hair?"

"Uh-huh."

"Oh, sometimes after thirty seconds. Sometimes I let a couple minutes go by. Never more than once in one minute. That would just be indulgent." Pam felt that same pit in her stomach that she felt on the night with Jyle and the giraffe. She welcomed the feeling this time, though. Pam stood up and extended her left hand to Izzy's right. Jaya took it and Pam led the two out of the diner. She completely forgot about her food and Tim and the check. All she could see was Izzy's right ear wiggle at unpredictable intervals. 